\title{
Orientalism Goes to the Movies: A Critical Discourse Analysis of The Dictator
}

\section{Rania Abdel Meguid*}

\section{Introduction}

Since the 9/11 terrorist attacks, Islam has been viewed by many in the West as a terrorist religion that only calls for Jihad and the oppression of all those who are different. As Dabashi $(2008$, p. 1) puts it, such attacks have once more raised "the specter of Islam as the principal nemesis of "the Western Civilization"". This contributed to spreading Islamophobia throughout the world, especially in Western countries where Islam is equated with the East and the Arab world. The issue has become one of the main themes that many Hollywood movies started revolving around. Despite the fact that Hollywood had always presented Muslims, Arabs and Easterners in a negative light since the 1920s, Orientalist representations of these groups started taking a more sinister turn with the passage of time, especially after the $9 / 11$ attacks. This paper attempts to investigate the representation of Muslims in Sacha Baron Cohen's The Dictator using a critical discourse analysis approach in an attempt to explore how the cinema contributes to the construction of the identities of the Self (the West, especially the US) and the Other (the East, which is equated with Arabs and Muslims) as well as how such Orientalist representations affect the audience's perception of the East and contribute to changing the international political scene.

\section{Review of the Literature}

\subsection{The Concept of Orientalism}

Said (2003, p. 5) states that "[t]he relationship between Occident and Orient is a relationship of power, of domination, of varying degrees of a complex hegemony". Until the $19^{\text {th }}$ century, the conflict between the East and the West took a military form. However, the end of Western military colonization of the East did not mark real independence, but rather gave way to what could be termed "cultural colonization". Said (1989, p. 206 - 207) argues that the experience of being "colonized" (a term which became synonymous with the

\footnotetext{
${ }^{*}$ Lecturer in the Department of English Language and Literature, Faculty of Arts, Alexandria University, Egypt.

Cairo Studies in English - 2020(1): https://cse.journals.ekb.eg/
} 
Third World) did not stop with the last white soldier leaving the country and the flag of the colonizer coming down; "[t]o have been colonized was a fate with lasting, indeed grotesquely unfair results, especially after national independence had been achieved". A mix of poverty, dependency, underdevelopment and various pathologies of power and corruption all made the colonized peoples feel that they have freed themselves on one level, yet remained victims of their past (ibid, p. 207). According to Nandy (1983, p. xi), the West at that point was concerned with a colonialism which would survive the demise of empires, and that was the time to turn to a second form of colonization. This can be termed "cultural colonialism" and could be achieved through what Said (1989, p. 211) refers to as an Orientalist "ideology".

According to Nicha $(2012$, p. 2), the term "Orientalism" was a Western coinage which appeared with De Gama's journey to the Cape in order to refer to the different cultures and civilizations outside Europe which were classified as "Oriental". Hence, the term "Orient" was used to describe non-European religions, cultures and civilizations and was soon associated with "mysticism, barbarism, despotism, imagination, non-rationalism, sexuality and violence" (ibid, p. 2). In other words, the Orient was everything the West was not. Later, the term "Orientalism" was introduced. Said (2003, p. 2) defines Orientalism as "a style of thought based upon an ontological and epistemological distinction made between 'the Orient' and 'the Occident'". In other words, it is a process through which the Orient is constructed in opposition to the Occident, hence creating binary oppositions between both. Because it is a Western style of thought, Orientalism is used to create binary oppositions between the East (them) and the West (us). These differences highlighted between the "Self" and the "Other", Pirnajmuddin and Salehnia (2006, p. 172) argue, serve as a pretext to justify patterns of exploitation and domination. Such differences between the East and the West, which have transformed into stereotypical images of Orientals in general and Muslims in particular, legitimize the way those "Others" are subjected to Western control. It is worth mentioning here that an Orientalist approach considers the Orient equal to Islam. As Aburaiya (2009, p. 57) explains, "the popular view in the West is that religion continues to form the fundamental identity of the Islamic Orient".

In order to justify its war against Islam, which is deemed to be the "Other", the West ideologically constructed it as the "new empire of evil" based on terrorism, violence and tyranny (Said, 2003, p. 347). In the light of this view, "Islam and by extension, Arabs, are seen as irrational, menacing, untrustworthy, anti-'Western', and dishonest" (Khalid, 2014, p. 5). These are elements of what Tuastad (as cited in Khalid, 2014, p. 5) calls "the new barbarism", an Orientalist 
term implying that "violence, corruption, and irrationality are embedded in 'Other' cultures". As Hall (1992, p. 188) puts it, the West has this tendency to treat "non-European cultures as different and inferior". Hence, Islam was viewed as a backward religion which contrasted with the "modern" West. Modernity, which is a major characteristic of the West, according to Pirnajmuddin and Salehnia (2006, p. 174), "marked a shift from religious concerns to the 'rational' ones of the world". Milton-Edward (as cited in Pirnajmuddin and Salehnia, 2006, p. 174) states that in Orientalist discourse,

Islam - as a culture and not only as a religious creed - was primitive, underdeveloped, retrograde, at best stuck in the memory hole of a medieval splendor out of which it could not disentangle itself without a radical transformation; and this could only be based on Western, rational, progressive values.

In the light of this definition, modernity could be equated with imperialism and hegemony over other nations and cultures through attempting to "Westernize" them. According to Inayatullah and Boxwell (as cited in Pirnajmuddin and Salehnia, 2006, p. 174), imperialism, as one of the manifestations of the darker side of modernity, "saw the history as a linear process towards Western capitalism and liberal secularism concluding with the transformation of the world into a single, global, western civilization" (emphasis mine). This could be best done via what Said (1993, p. 9) terms "cultural imperialism". Said argues that "in our time, direct colonialism has largely ended; imperialism [...] lingers where it has always been, in a kind of general cultural sphere as well as in specific political, ideological, economic and social practices".

The West has always considered that the Orient and the Muslim world were everything the West was not. The picture which the West has propagated was an intensified version of the binary opposition between "us" and "them". "We" are good, whereas "they" are evil; "we" are rational, whereas "they" are irrational; "we" are civilized, whereas "they" are barbaric; "we" are progressive, whereas "they" are backward. Such binary oppositions were instrumental in justifying the West's interference in Eastern affairs and, moreover, its conflicts with the East. Khalid (2014, p. 3) argues that Bush's "war on terror" after the 9/11 attacks was characterized by the West as a conflict between "good" and "evil", between "civilization" and "barbarity". 


\subsection{Orientalism in Movies}

According to Shaheen (2001, p. 9), "[f]ilm criticism is an integral part of the cultural landscape". For many Americans (and Westerners in general), Hollywood movies are a kind of window through which they see the world outside their countries. However, the representations presented in such movies have not always been fair or objective. This is because Europe (and the West in general) has used its history of cultural, intellectual and scientific advancement in imposing its hegemony over the cultures of the rest of the world, defining them from a Western perspective (Nicha, 2012, p. 2). As Shaheen (2001, p. 9) argues, "[a]llegations of the moviemakers' discriminatory practices are hardly new". Accordingly, despite the fact that most Eastern countries have been liberated from Western colonization, the colonial/imperial paradigm did not die with the formal end of colonialism, for the media has always played a major role in categorizing and generalizing "the West versus the East, the black versus the white, the Hispanics, the Arabs, the Muslims, the Jews, etc." (Bassiouney, 2012, p. 111), and films are a case in point. As Shohat and Stam (2014, p. 121) put it, "one could speak of a "submerged" imperial presence in many films".

This "Eurocentrism", as referred to by Shohat and Stam (2014), which dominated the cinema industry, continues to depict Europe (and the West in general) as the sole source of culture, promote the narrative of Western progress and superiority and demonize non-Westerners through "otherizing" them (Majzoub, 2017, p.7). This could be explained in terms of Nicha's $(2012$, p. 4) argument that Hollywood is a corporate media system which is influenced and manipulated by news media owners, politicians, filmmakers with radical political positions, the Department of Defense and the CIA. Simson (1996, para. 2) argues that Hollywood movies have always presented negative representations of almost every minority group in the world such as blacks, Native Americans, Asians and Arabs. However, although Simson (1996, para. 2) thinks that almost all minority groups have been poorly treated by Hollywood movies, he argues that Arabs (who are equated with Muslims) have always had the biggest share of unfair representations.

As Majzoub (2017, p. 9) puts it, many Hollywood movies are "peppered with stereotypes against Arabs". Nicha (2012, p. 2) argues that Hollywood imagery has always used oversimplified depictions and negative stereotypes of Arabs, which contributes to shaping the American people's negative perception of Arabs (and hence Muslims). Such negative stereotypes of Arabs "have been created to frame a whole culture" for "Arabs have been deliberately painted and molded to fit into a unilateral pattern of representation, where they get consistently portrayed as filthy barbarians and hateful thugs" (Majzoub, 2017, p. 
3). In fact, it has been argued that one of the main aims of Orientalist art is "to show the Islamic world in a position of either moral or cultural inferiority to that of the West" (AJ+, 2017). However, such stereotypes, Shaheen (2001, p. 7) argues, were not first created by moviemakers; rather, they were inherited from pre-existing Arab caricatures created by writers and artists in the $18^{\text {th }}$ and $19^{\text {th }}$ centuries. The images presented by those writers and artists of the Arabs and their world were of "desolate deserts, corrupt places, and slimy souks inhabited by cultural "other" - the lazy, bearded heathen Arab Muslim" (Shaheen, 2001, pp. $7-8$ ). In addition, the tales created by those writers "were inhabited with cheating vendors and exotic concubines held hostages in slave markets" (ibid, p. 8). Hence, such images were not new. Rather, they were recreated by filmmakers.

Simson (1996) traces the history of the negative representation of Arabs and Muslims in Hollywood movies, arguing that it goes back to as early as the silent movie era of the 1920s. According to Nicha (2012, p.4), Hollywood movies started in the 1920s to represent Arabs as the Other in order to highlight American supremacy, and in so doing, they have always represented them as narrow-minded, stupid, rich oilmen or as barbaric and blood-thirsty kidnappers (ibid. p. 4). Such representations contribute to shaping the Western audience's perception of Arabs, Muslims and Middle Easterners who are depicted in an extremely negative light. For example, Simson (1996) states that "Rudolph Valentino's roles in The Sheik (1921) and Son of the Sheik (1926) set the stage for the exploration and negative portrayal of Arabs in Hollywood films" as Arabs in these movies were depicted as "thieves, charlatans, murderers, and brutes" (para. 3). Many other movies during the 1920s portrayed Arabs negatively; examples include The Song of Love (1923), which is about a power-hungry Algerian chief; A Cafe in Cairo (1924), which is about an Arab desert bandit who kills a British man and his wife to marry their daughter; and The Desert Bride (1928), which is about a group of Arabs who torture a French officer and his lover.

Simson (1996) argues that the stereotypes of Arabs and Muslims in Hollywood movies barely changed in the 1970s and 1980s. In his article in which he analyzes two Orientalist movies (namely Skyfall and Taken 2 respectively, both of which take place in the Muslim country of Turkey), Akser (2014, p. 35) argues that "[c]lassical Orientalism produced its own discourse, and everything written and drawn is recycled from previous material". This could be linked to the idea of propagating American supremacy proposed by Nicha (2012). By the late 1980s, it seems that the movies which represented Arabs and Muslims negatively revolved mainly around the theme of terrorism. Until the 1980s, 
movies about terrorism focused on Nazis and Russians (Boggs \& Pollard, 2006, p. 338). By the late 1980s, when Arabs and Muslims had already been at war with Israel and, to a lesser extent, the US for a long time, Arab/ Muslim militants replaced Nazis and Communists as "larger-than-life screen villains" who are "semi-civilized, violent, shady, beyond redemption, capable of horrendous crimes - traits making them suitable for extermination" (ibid, p. 338). Boggs and Pollard (2006, p. 338) cite an example of such movies which is Delta Force 3 (1991); the movie presents a group of Palestinians, assisted by a crazed sheikh, who try to blow up Miami while shouting "Allah Akbar" (which definitely indicates that they are Muslims and, hence, contributes to the depiction of Muslims as terrorists). Another example they cite is Frantic (1988) which represents Arabs as a group of drunken kidnappers who try to obtain stolen devices to start a nuclear explosion (ibid, p. 338).

Simson (1996) argues that although more accurate depictions of Arabs were expected in the 1990s, as an age of political correctness started, this was not, in fact, the case. Examples include Navy Seals (1990), which is about a group of Palestinians who steal US-made Stringer Missiles while keeping an American helicopter as hostage; American Ninja 4: The Annihilation (1991), which is about a sheikh who receives his punishment after trying to bomb New York City; Patriot Games (1992), which is about the US bombing of a terrorist camp in Libya, including Libyan, Palestinian and Syrian terrorists; and Chain of Command (1993), which is directed by the Israeli producer Yoram Globus and revolves around a group of Arab terrorists taking American hostages to the fictitious Republic of Quimir. Even children's movies could not escape involving Orientalist ideologies. One very popular movie which presents an Orientalist view is Aladdin (1992) which is a children's movie and to which frequent reference is made in the movie The Dictator (2012) which is analyzed in this paper. Professor Walter Denny, who is a distinguished professor of Islamic art, argues that this movie is basically a prejudicial movie which creates "a very, very false impression and very, very prejudicial view of the Islamic world" (AJ+, 2017). Aladdin is a movie which describes a made-up Arab land as a "barbaric" land where "they cut off your ears if they don't like your face". When this movie was released, Dr. Jack Shaheen responded in the Los Angeles Times, arguing that it was "a painful reminder to 3 million Americans of Arab heritage, as well as 3 million Arabs and others, that the abhorrent Arab stereotype is as ubiquitous as Aladdin's lamp" (AJ+, 2017). Being a children's movie, this movie is expected to instill in children hatred of "barbaric" Arabs and Muslims at a very early age. 
The 2000s did not bring much change regarding the misrepresentation of Arabs and Muslims in Hollywood movies. Movies presenting Arabs and Muslims as terrorists during this period include Munich (2005), which revolves around a Palestinian terrorist group killing 11 Israeli members of the 1972 Munich Olympic team; Zero Dark Thirty (2012), which revolves around Maya, a CIA operative who does not like to use violence against detainees but finds out that she has to in her attempt to find the whereabouts of Osama Bin Laden after the 9/11 attacks; and Captain Phillips (2013), which revolves around a group of Somalis who pirate an American ship and torture its captain and crew. Although a movie like Body of Lies (2008) tries to go beyond stereotypes of Muslims and Arabs as terrorists, for agent Roger Ferris (Leonardo DiCaprio) can memorize verses from the Quran in Arabic, falls in love with a Jordanian woman, and eventually decides to stay in Jordan and leave the CIA, the movie still presents Arabs and Muslims as terrorists who bask in violence and deception. On another note, although Victoria and Abdul (2017), in which the central character is an Indian Muslim who falls in love with Queen Victoria, does not present Muslims as terrorists, it still presents them as inferior beings who look up to the West and feel inferior to it. The scene in which Abdul falls on his knees to kiss Queen Victoria's foot shows him in a humiliating light. On the other hand, Queen Victoria knows nothing about India (which she officially rules) except that it is an exotic land full of wonders and fruit that does not grow in her land. In addition, Abdul's friend, Mohammed, is presented as a sick, ignorant, heavybearded man who is reluctant to civilization and who dies miserably in the end after failing to embrace the culture of the superior land. Accordingly, it seems that the 2000s Hollywood movies still followed the same line of presenting Arabs/Muslims/Easterners as terrorist, backward peoples who are, in every respect, inferior to the civilized West.

Boggs and Pollard (2006, p. 347) argue that the ideological biases presented in such movies are "rendered all the more effective because of their seemingly non-political content". Nicha $(2012$, p. 7$)$ thinks that the negative depictions that Hollywood movies present of Arabs and Muslims, which contribute to spreading Islamophobia and hatred of Arabs and Muslims, serve to justify the violent actions taken by the US against the Middle East and, hence, the US military interference in the Middle East. As Boggs and Pollard (2006, p. 347) argue, when Arabs and Muslims are presented as such in movies, the message that is conveyed to the audience is that such enemies "challenge the very foundations of US national security, Western civilization, and global order". Hence, it is no wonder that when the US was bombing ISIS in Iraq and Syria, 30\% Republican voters voted for the destruction of "Agrabah", which is, ironically, the fictional 
"barbaric" land in which the events of Aladdin (1992) took place, simply because it is an Arab land (AJ+, 2017). That is when military interference in the Middle East, in the affairs of Arabs and Muslims, becomes a heroic, noble act.

\section{Methodology}

This paper adopts an eclectic approach in order to reveal how Arabs and Muslims are negatively represented in The Dictator (2012). The paper draws on critical discourse analysis (CDA) through using the Ideological Square proposed by van Dijk (1998) to analyze the representation of Self and Other combined with a model proposed by Bassiouney (2012) which offers a number of linguistic tools that can be used as a means of constructing identity. Since the data analyzed is a movie, the analysis makes use of the elements of an audiovisual text proposed by Zabalbeascoa (2008).

\subsection{Critical Discourse Analysis}

Fairclough (1989, p. 22) views discourse as "language as a form of social practice". Accordingly, discourse is both socially constituted and socially constitutive. According to Sunderland (2004, p.11), discourse is socially conditioned because it is shaped by material and social structures. In addition, it is socially constitutive because it is "not only a form of knowledge about cultural ways of thinking and doing, but also, more powerfully, a potential and arguably actual agent of social construction" (Litosseliti \& Sunderland, 2002, p. 13). In other words, the context in which discourse is produced influences textual instances and these texts, in turn, "have an effect on social reality" (Zotzmann \& Regan, 2016, p. 115).

In order to be able to reveal the ideologies and power relations enacted in discourse, researchers use critical discourse analysis (CDA). Van Dijk (2001, p. 352) defines CDA as "a type of discourse analytical research that primarily studies the way social power abuse, dominance and inequality are enacted, reproduced, and resisted by text and talk in the social and political context". In other words, it starts with the prevailing social problems with the aim of ending the suffering of those who suffer and critically analyze the discourse of those in power and those who have the means of solving such problems (van Dijk, as cited in Wodak, 2001, p.1). Hence, as Zotzmann \& Regan (2016, p. 114) put it, CDA is committed to critiquing "problematic social practices with a view of transforming them for the better". Sunderland and Litosselilti (2002, p. 19) state that CDA is concerned with social injustice, inequality, power and power struggles, but it is also concerned with "exposing the often subtle role of discourse in the construction and maintenance of injustice, inequality and 
domination". In Cameron's words (as cited in Sunderland and Litosselilti, 2002, p. 19), CDA is concerned with exposing "the hidden agenda" of discourse. This can be done through an investigation of language structures as, according to Habermas (as cited in Wodak, 2001, p. 2), language is a medium of domination and social force since it serves to legitimize power and power relations. According to Fairclough $(1989$, p. 5), CDA is described as "critical" as it aims to investigate connections which may not be noticed by people, such as the connection between language, power and ideology. Wodak $(2001$, p. 9) adds that CDA is to be understood as "critical" since it should deal with the data objectively, embed the data in the social and take an explicit political stance. As Meyer (2001, p. 15) argues, being critical sets CDA apart from other disciplines in that it plays an important role in the lives of those who suffer from social discrimination. CDA helps increase people's consciousness of how language contributes to some people dominating others as raising awareness of this fact is the first step of emancipation (Fairclough, 1989, p. 1).

According to Wodak (2001, p. 3), CDA, hence, could be viewed as a means of resisting "unequal power relationships that appear as societal conventions". The effects of power and ideology naturalize such inequalities in language structures, and hence, CDA tries to resist such inequalities through breaking such conventions. Van Dijk (as cited in Lazar, 2005, p. 6) argues that the analysis of discourse which reveals the workings of power and how they sustain oppressive structures and relationships is itself a form of "analytical resistance" which contributes to on-going struggles of contestation and change. According to van Dijk (1995, p. 19), successful CDA should be effective, not only descriptive and explanatory; "[i]ts conclusions, recommendations and other practical interventions must work".

3.1.1. Ideology and Power. Among the main concerns of CDA are the concepts of ideology and power. The two concepts are closely related since it is ideologies, naturalized by discourses through presenting them as "common sense", that help maintain power relations between different social groups. Wodak (2001, p. 10) states that the term "ideology" first appeared in France in the late $18^{\text {th }}$ century, and its meaning has been changing ever since. She quotes Thompson's definition of ideology which goes as follows: ideology is a study of "the ways in which meaning is constructed and conveyed by symbolic forms of various kinds" (Wodak, 2001, p. 10). According to Schäffner and Kelly-Holmes (1996, p. 2), ideology is a property of language and discourse in the sociocultural context. In other words, it is "discursively constituted". According to Fairclough, ideology is closely related to language because language is the most 
common social behaviour and the social behaviour where we rely most on "common sense" (1989, p. 2). Fairclough (1989, p. 85) argues that ideologies are most effective when they are least visible, and their invisibility could be achieved through bringing them into discourse not as explicit elements of the text, but as background assumptions (i.e. common sense).

Sunderland $(2004$, p. 8$)$ argues that discourses are basically ideological flows of information which construct the world through language and texts. Ideologies serve to maintain unequal relations of power and dominance (Lazar, 2005, pp. 6 - 7; Weiss and Wodak, 2003, p. 14), hence sustaining the interests of a certain group (Van Dijk, 1998, p. 24). CDA aims to study the ideology of those who are in power and who are responsible for the suffering of others (as presented in texts) in an attempt to produce enlightenment and emancipation and better the conditions of those who are oppressed or unfairly treated.

The concept of power is another major concern of CDA. Wodak (2001, p. 11) argues that power is about relations of difference and the effects of difference in social structures. Language is a major tool of maintaining power. However, CDA scholars maintain that language is not powerful on its own, but rather gains power when used by powerful people (Weiss and Wodak, 2003, p. 14).

Fairclough $(1989$, p. 2) argues that ideology and power are closely related since ideologies naturalize and legitimize existing power relations and differences of power. Fairclough (1989, pp. 3 -4) argues that there are two types of power. The first type is coercion manifested in acts including physical violence. The second type involves one group exercising power over another through manufacturing the latter's consent. This could be done through ideology which naturalizes power relations and differences of power. According to Holmes, who considers power a "systemic characteristic", systemic power "typically goes unquestioned because it is firmly based in conventional wisdom; its contestable status is simply one of the taken-for-granted, self-evident truths or background assumptions of our everyday talk in which it is constantly instantiated" (2005, p. 32). As van Dijk (2006, p. 792) puts it, ideology plays a role in legitimizing power abuse through presenting it in discourse as "common sense". Holmes states that CDA aims to explore how the powerful construct and reinforce power in interaction and describe the processes by which dominant groups influence the directions in which power develops (2005, p. 32).

3.1.2. Racism, Stereotyping and the Construction of Identity. Edwards (2009, p. 20) argues that "[ $t]$ he essence of identity is similarity; things that are identical are the same". According to Ulinnuha, Udasmoro and Wijaya (2013, p. 262), "the issue of identity questions the relationship between particular entities 
such as society, religion and culture". As far as group identity is concerned, it is determined by sociological variables such as race, ethnicity, nation, religion, sex and age (Omoniyi, 2011, p. 261).

Van Dijk argues that CDA treats identities as effects of "ideological work". He argues that the identity and social interests of a group are basically constituted by ideologies (van Dijk, 1998, p. 25). Therefore, ideologies can be regarded as group "self-schemata" that define group features and determine the position of a certain group among other groups, and hence the relationships between different groups. "Because these schemata are ideological, the way groups and their members represent themselves and others may of course be biased" (van Dijk, 1998, p. 25) as "ideologies are the axiomatic basis of the social representations of a group" (van Dijk, 2006, p. 730). The attitudes and opinions of group members about themselves and others are represented in "mental models"; such models are characterized by being subjective, personal, individual and contextbound (van Dijk, 1998, pp. 26 - 27; van Dijk, 2006, p. 730), which explains why group representations of Self and Other are most likely to be biased. Since identity is a "discursive phenomenon", "representations of self and other are coconstructed through language and other semiotic resources" (Zotzmann \& O'Regan, 2016, p. 113). Accordingly, biases show in discourses (e.g. texts, films, etc.) produced by a certain group, especially if it is powerful and hegemonic since minorities and weaker groups "lack access to mainstream media" and hence they get "negatively represented by it" (Omoniyi, 2011, p. 264).

Ideological representations of groups can be analyzed using the tenets of the Ideological Square proposed by van Dijk. According to van Dijk (1998, p. 267; 2006, p. 734), ideological discourse often features the following strategies:

- Emphasize Our good things

- Emphasize Their bad things

- De-emphasize Our bad things

- De-emphasize Their good things

Such representations serve the power interests of powerful groups. Herschinger (2011, pp. $12-13)$ argues that

[a]n equivocal, radically different, and menacing Other is as much needed as the creation of an accordant unambiguous vision of the Self which is based upon a political consensus among the discursive 
agents jointly opposing the other and, thereby, allowing the enactment of internationally accepted measures countering the other.

As far as the representation of Islam and Muslims is concerned, "the reporting of Islam and Muslims is founded upon a structuring of presuppositions, themes and arguments indicative of van Dijk's ideological square" (Richardson, 2004, p. 69). In other words, in many Hollywood films, the good traits of Arabs and Muslims are minimized, whereas their bad traits are maximized, which results in stereotyping them as ignorant, barbaric terrorists. Such representations/stereotypes serve as a justification for American interference in the affairs of Arab and Eastern countries under the pretext of combating terrorism and securing world order. Hence, as Herschinger (2011, p. 29) puts it, "representing the Other as threatening is an essential component of security policies".

\subsection{Aspects of the Audiovisual Text}

Since stereotyping in films is established through the construction of characters, plot, images, sound and acting (Schweinitz, 2011, p. 42), the paper presents an analysis of The Dictator using the elements of an audiovisual text proposed by Zabalbeascoa (2008). According to Wildfeuer, (2014, p. 1), "[m]eaning in film arises out of the multiple interaction of various modalities such as images, sounds, music, gestures, camera effects, etc., which are stringed together by film editing in a chronological, linear order". This combination results in a text which needs the spectator to participate actively in order to be able to comprehend and interpret it (ibid, p. 1).

Zabalbeascoa $(2008$, p. 21) defines an audiovisual text as "a communication act involving sounds and images". It is "the projection of the film onto the screen for a given audience" (ibid, p. 22). According to Zabalbeascoa (2008, p. 24), there are four main components of the audiovisual text as illustrated by the following diagram:

Audio Visual

\begin{tabular}{|c|c|c|}
\cline { 2 - 3 } Verbal & Words heard & Words read \\
\cline { 2 - 3 } Non-verbal & Music + special & The picture \\
effects & photography \\
\hline
\end{tabular}


All these elements are combined to produce an audiovisual text (i.e. discourse) through which filmmakers can construct the identity of certain social groups.

\subsection{Speakers' Choice of Words and Identity Construction}

Since part of Zabalbeascoa's (2008) model involves the analysis of audio verbal material (i.e. the words heard), this paper makes use of a model proposed by Bassiouney (2012) to analyze how identity is constructed through speakers' speech. This is because "[i]dentity, national, social and collective is not necessarily what one 'is' but what one believes s/he is. It is directly related to self perception" (Bassiouney, 2012, p. 111). Accordingly, analyzing the audio verbal material (i.e. the words spoken by the characters in the film analyzed) can reveal how they are aimed to be represented and, hence, contributes to understanding how their identities are constructed in the text. Hence, this model can be used to analyze the words spoken by Muslim characters vs. the words spoken by non-Muslim characters (especially Americans) in the film in order to reveal the difference between Self presentation and Other presentation.

Bassiouney (2012, p. 111) argues that there are a number of linguistic resources used by speakers that can reflect how they view themselves and others as well as contribute to the construction of their, as well as others', identities. These can be divided into discourse resources and structural resources.

A) Discourse resources:

- Mention of identification categories such as ethnicity, locality and common past experiences

- Evaluative and epistemic orientations

- Implicatures and presupposition

- Metaphors, metonymy and synecdoche

- Intertextuality/ interdiscursivity

- Dialogicality

B) Structural resources:

- Pronouns

- Tense and aspect

- Deixis and negation

- Mood and modality

- Phonological, structural and lexical variation

- Code-switching and code choice 
These linguistic resources, combined with the elements of the audio visual text and the tenets of the Ideological Square, are employed in the data analysis in order to reveal how the Muslim and non-Muslim (i.e. American) characters are represented differently in the film in a way that contributes to a positive selfpresentation of Americans and a negative other-presentation of Muslims and Arabs.

\section{Data}

\subsection{Sacha Baron Cohen}

The data analyzed in this paper is The Dictator, a film starring and co-written by the British actor and comedian Sacha Baron Cohen, long known for his works in which Arabs and Muslims are stereotyped and negatively represented. According to the IMDb website, Baron Cohen was born in London to a British father and an Israeli mother, both of whom were of Jewish descent. Being halfIsraeli might have something to do with the kind of comedy he presents which, according to Alonso (2016, p. 584), "can be partly described as ethnic humor, a humor directed at satirizing alleged attributes of racial and nationality groups" who in most cases happen to be Arabs and/or Muslims in his movies (emphasis mine), given the long history of conflict between the Arabs and Israel. Indeed, although Baron Cohen's works are classified as comedies, Atluri (2008, p. 4) argues that his comedy "can be situated in a broader genealogy of 'race' based humour", which "risks reinscribing 'race' by offering up the figure of "the Other" as an object of ridicule" (ibid, p. 10). This applies to several controversial characters which were played by Baron Cohen and which seemed to serve as a ridicule of Arabs and Muslims.

Among the controversial characters played by Baron Cohen in some of his works are Ali G, Borat and General Aladeen, all of which are characters which have "consistently provided comedy that leads to public debate in the relationship between comedy and race, ethnicity and stereotype, and the nature of racism and 'othering' in comedy" (Weaver \& Bradley, 2016, p. 1). Ali G is a white gangster from the middle-class London suburb of Staines who hosted a TV show, and the name "Ali" suggests that he is a Muslim. Borat is the central character in a film of the same name which was produced in 2006, a character "which combines Islamo-Arabic foreignness with a Soviet touch" (Alonso, 2016, p. 593). Borat is a reporter from Kazakhstan (an Eastern country) who appears in the film to be anti-Semitic and sexist and to violate all social taboos with his outrageous behaviour and viewpoints. Both characters, Alonso (2016, p. 582) argues, "were being set up for comic situations that prompted selfrevealing prejudices and racial, sexual, social and cultural tensions", in this case 
against Arabs/Muslims/Easterners. General Aladeen is the central character in The Dictator which is analyzed in depth in this paper.

\subsection{The Dictator}

Sacha Baron Cohen's The Dictator (2012) is a film about General Aladeen, a despotic tyrant and an ardent supporter of Bin Laden. General Aladeen rules the fictitious land of Wadiya with an iron fist and is manufacturing nuclear weapons to attack Israel, which leads the United Nations Security Council to make a decision of military interference in Wadiya. Aladeen travels to the US to attend a security conference in an attempt to solve the problem, but he is kidnapped, with the help of his uncle, shortly after he arrives, and his uncle sends a substitute to replace him at the conference. After Aladeen manages to escape from his kidnapper, he meets Zoey, a human rights activist, and later they fall in love with each other. When he confesses his true identity to her, she is shocked and decides to leave him as she cannot fall in love with a cruel dictator. Aladeen manages to reach the conference and tears the document of democratizing Wadiya before the eyes of the world. At the end of the film, Aladeen goes back to Wadiya with Zoey and marries her. He holds the first democratic elections in Wadiya, but they are rigged in his favour.

There are a number of reasons why this film has been chosen for analysis. The first reason is that it is a prototypical Orientalist movie. Although there are several movies which present negative images of Muslims, this movie, as Weaver and Bradley (2016, p. 3) put it, "is replete with signifiers that are stereotypic of Islam and Muslims - from the name 'Aladeen', his long beard, misogyny, anti-Semitism, and anti-Americanism". Second, the film is classified as a comedy, and studying the creation of racialization through humour "allows one to see the ways in which comedy might shed light upon, negotiate, and produce changing meanings of 'race' in contemporary social life" (Atluri, 2008, p. 4). Hence, the movie is analyzed in order to investigate how the comic effects of the movie contribute to stereotyping Muslims, leading to racism against them. Finally, although the film is quite recent, it adopts the same Orientalist perspective adopted by earlier films in addition to an indication in a number of scenes that the despotism of Muslims/Arab/Eastern rulers serves as a pretext for the West to interfere in the affairs of these countries, which is the ultimate aim of Orientalist discourse. The reasons for interfering in the affairs of Wadiya mentioned in the film are no different, for example, from the justifications announced for the invasion of Afghanistan (fighting Bin Laden and Al-Qaeda) and Iraq (fighting Saddam and ridding the world of mass destruction weapons). 
Hence, though fictitious, the film presents a political situation not very different from the real political situation involving the US and the East.

\section{Data Analysis}

This section presents an analysis of Sacha Baron Cohen's The Dictator using the elements of analysis presented by Zabalbeascoa (2008), namely visual-verbal material, visual-nonverbal material, audio-verbal material and audio-nonverbal material. The analysis aims to investigate how these elements are combined in the film to construct two opposing identities of the Self (the West) and the Eastern/Islamic Other. Using the model proposed by Bassiouney (2012), the audio-verbal material (i.e. commentary and dialogues between characters) is also analyzed in an attempt to investigate how the speakers' words are intended to construct their own identities in addition to the identities of the Other. Van Dijk's Ideological Square is used to highlight the differences between the positive presentation of the Self (America) and the negative presentation of the Other (Islam).

\subsection{Visual-nonverbal material}

Zabalbeascoa (2008, p. 22) argues that the presence of an object in an audio-visual text "might be perceived as related to somebody trying to communicate something through that object, either as a symbol or part of a special code-system". A number of images in The Dictator seem to be there in order to communicate certain messages about Muslims, hence contributing to constructing their identities in an Orientalist light. One image that is frequently displayed

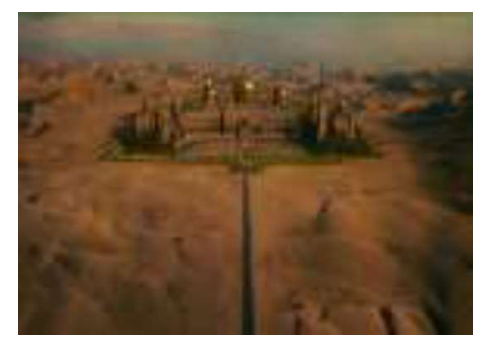

Picture 1: Mosques in Wadiya on the screen as part of Wadiya is a picture of mosques with their domes surrounded by vast, stretching desert (Picture 1). Such images serve to establish the setting of the film, creating a stereotypical image of the Muslim country of Wadiya (as the mosques show) whose population still lives in the desert. Such an image contributes to otherizing the Eastern/Muslim world as backward as opposed to the modern West with its latest cars and technology.

One of the early images that appear in the movie is a picture of Admiral General Aladeen (played by Cohen) who is the despot ruling the Muslim land of Wadiya. In this picture, Aladeen appears with his "iconic beard" as the commentary goes in the background (Picture 2).

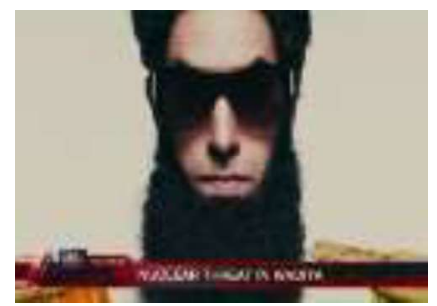

Picture 2:

Aladeen's iconic beard 
Combined with the pictures of mosques frequently displayed on the screen, this picture seems to present a stereotypical image of Muslims and to trigger in the minds of the audience images of terrorist groups like al-Qaeda; there is a picture of Osama Bin Laden with his similar beard at some point in the film, apart from the fact that Aladeen keeps mentioning his name as one of his close friends. Later, there is another picture of Aladeen on horseback, wearing a white galabiya and

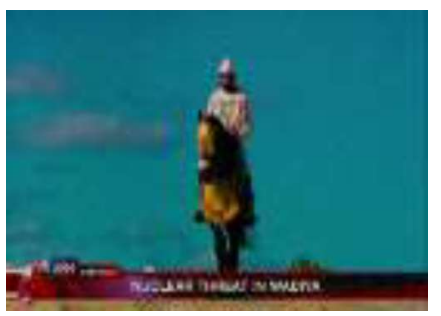

Picture 3: Aladeen in the desert a white head cover and riding his horse in a vast desert (Picture 3). The clothing is stereotypical of Muslim men, and riding a horse in the desert seems to depict the Eastern/Muslim world as a primitive place as opposed to the advanced West, which further contributes to constructing Easterners and Muslims as the Other.

Ironically, when Aladeen travels to America in order to convince the international community to remove the sanctions imposed on Wadiya for manufacturing nuclear weapons, he and his procession arrive on camels which they ride on the streets of New York (Picture 4). The striking difference between the camels that Aladeen and his men ride and the latest cars of the city seems to highlight a kind of binary opposition between the backward East (the Other) which still lives in the past and rides camels and the advanced West (the Self) with its technology and progress.

In addition to being represented as backward terrorists, Easterners and Muslims in the film are also represented as sex fiends. Alonso (2016, p. 584) argues that 'Baron Cohen's humor is characterized by its obsession with the body and its functions" and that is why there are plenty of scenes displaying sexual practices in his films. The scenes displaying sexual practices in The Dictator seem to contribute to the construction of Easterners'/ Muslims' identity via representing them as obsessed with sex. Since his early childhood, Aladeen has always been surrounded by sexy women (Picture 5). As he grows older, he has a staff of female guards who, in addition to guarding him, take care of his sexual pleasure (Picture 6).

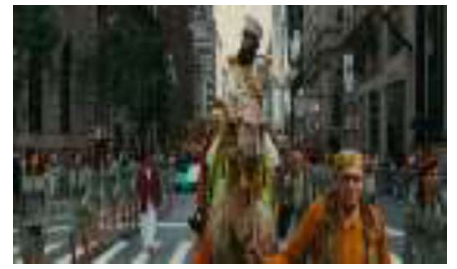

Picture 4: Aladeen on a camel in New York

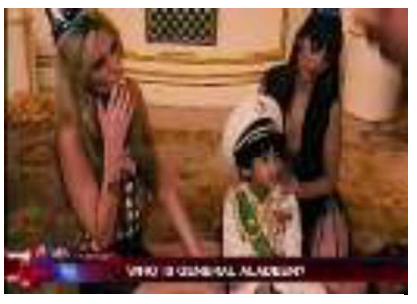

Picture 5:

Women in Aladeen's childhood

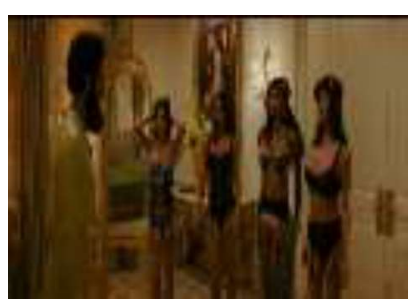

Picture 6:

Aladeen's obsession with women 
Aladeen's obsession with having sex (with both men and women) shows in the enormous wall covered with pictures of all the people he has had sex with, for he takes a picture with each person he has sex with after each intercourse. The huge wall in his bedroom is covered with what seems to be hundreds of pictures, signaling the hundreds of intercourses he has had with both men and women (Picture 7, 8 and 9).

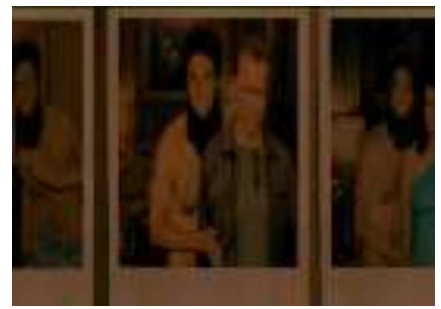

Picture 7:

Aladeen having sex with men

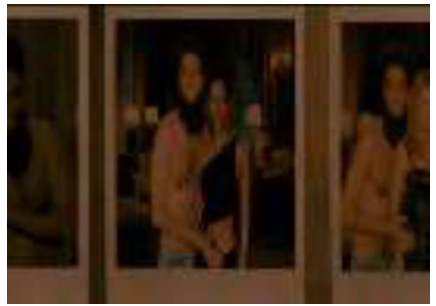

Picture 8:

Aladeen having sex with women

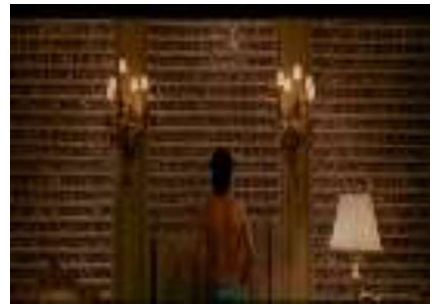

Picture 9: Aladeen pondering over his sexual relationships

The picture of the Wadiyan people bringing down Aladeen's statue on the streets (Picture 10) bears intertextuality to the picture of the Iraqi people bringing down Saddam Hussein's statue on the streets of Baghdad. The caption in the movie runs "End of a Dictatorship", which brings to mind the pretext under which the US invaded Iraq in 2003: saving the Iraqi people from the dictator Saddam Hussein. The movie seems to convey to the audience this message: it is the US' duty to interfere in the affairs of Eastern countries to save them from

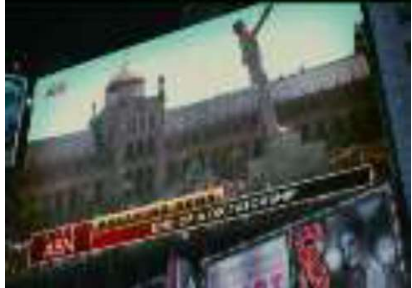

Picture 10:

Toppling Aladeen's statue in Wadiya their dictators, which shows how discourse serves to naturalize and even legitimize power relations and the desires of powerful parties. It also seems to create a binary opposition between the despotic East (the Other) and the democratic West (the Self), which further contributes to a positive presentation of the Self and a negative presentation of the Other.

\subsection{Visual-Verbal Material}

The visual-verbal material used in the film includes basically signs that are written in the Wadiyan language (Pictures 11 and 12). This language is a madeup one, but it is made-up in such a way that it looks like Eastern languages; the letters look very much like Arabic or Urdu letters, but they belong to neither. The letters, looking Oriental, combined with the pictures of the mosques, the deserts and the beard, contribute to creating a completely different world from 
that of the West, which further contributes to intensifying the audience's feelings that the East is the different "Other".

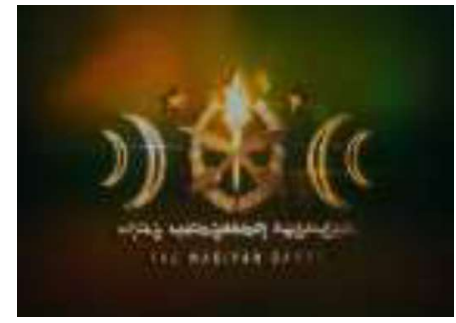

Picture 11:

The Wadiyan language

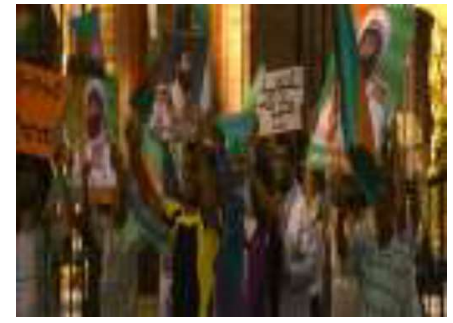

Picture 12:

Signs Supporting

Aladeen in Wadiyan

\subsection{Audio Non-Verbal Material}

Sounds and music constitute a basic part of an audio-visual text, and in the film analyzed in this paper, combined with the images, they contribute to creating an Oriental atmosphere. This is because "[t]he emotional associations generated by music attach themselves automatically to the visual focus of attention or the implied topic of the narrative" (Cohen, 2001, p. 250). Accordingly, the music used in the film puts the audience in a certain mood and almost flies them to the setting where the story takes place (i.e. an Oriental world). As Zabalbeascoa (2008, p. 24) argues, the music, the script and the photography "all add up and combine with each other, so that viewers can interpret them in certain ways".

Zabalbeascoa $(2008$, p. 24) states that " $[\mathrm{t}] \mathrm{h}$. music in a film may be original or not", and The Dictator includes both types. One thing about the music used in the movie that draws attention is that the music, both original and unoriginal, is Arabic music whether it is accompanied by words or not. It is worth mentioning here that while Aladeen states in one of the scenes that he is not an Arab, all the music and songs played are Arabic music and songs, which reiterates the idea that for many Westerners, the items "Arabs", "Muslims" and "Easterners" are used interchangeably.

The very first sound that is heard and that is played for 38 seconds even before any scenes appear on the screen is somebody signing in Arabic with a sad tone "ya "eini, ya leili" (literally "O, eyes, $\mathrm{O}$, night"), which is a cliché beginning for dozens of Arabic songs. In second 38, the music that starts playing is Western music, but it is the very same music played in a well-known Arabic song performed by Amr Diab, one of the most universally acclaimed Arab singers, so it still belongs to an Arabic song. Another soundtrack that is played during the film is a song entitled "golo lmama" (literally "Tell Mom") performed by the 
Moroccon singer Cheb Rayan. One unoriginal song played repeatedly throughout the movie is a song about Aladeen himself, hailing him as the ruler of Wadiya. Although the song is not an original one, it is still played in Arabic. Hence, the fact that the movie makes use of Oriental music and songs with Arabic lyrics is telling about what kind of atmosphere the movie makers are seeking to create, which, along with the images, contributes to the establishment of the Orient as an exotic place which is completely different from the West and hence an "Other".

\subsection{Audio Verbal Material:}

Audio verbal material refers to the words heard throughout the film, mainly the words uttered by the characters or by a narrator. Due to space constraints, only a number of key conversations and utterances are analyzed using Bassiouney's (2012) model. The conversations and utterances analyzed are selected as they are representative of the stark differences between the positive representation of the Self (Americans) and the negative representation of the Other (Muslims and Arabs).

\section{Extract 1:}

TV Reporter: Tensions are rising as the stand-off between the world community and the rogue North African nation of Wadiya intensified today as UN weapons inspectors were once again refused access to the country by Wadiyan leader, Admiral General Aladeen. Tonight we ask who is General Aladeen. According to Wadiyan propaganda, Haffaz Aladeen was born in 1973. He did not know his mother who died in childbirth. General Aladeen was born the only son of Colonel Aladeen, himself a savage and violent dictator. Known for his iconic beard, he is protected by thirty female guards, who he maintains are virgin. Thrust into power at the age of 7 , he may just be the most dangerous man in the entire world. Eccentric and with unlimited oil wealth, he recently hosted his own Olympic games, at which he won fourteen gold medals. Often described as ignorant, he changed over 300 Wadiyan words to "Aladeen", including the words "positive" and "negative", casing mass confusion.

In this extract, the American TV reporter makes use of a number of discourse as well as structural resources that contribute to presenting an image of Aladeen as the complete opposite of America which is a democracy. One of the key 
discourse resources used in this extract is the intertextuality that the very name Aladeen bears, for it is an Arab name and the title of a key Orientalist cartoon movie which presents Arabs and Easterners as cruel savages. The name, hence, triggers an image of Arabs (and hence Muslims) as cruel and uncivilized peoples in the minds of the audience, which helps in constructing their identity as savages. This effect is intensified by the evaluative orientations used by the reporter. Wadiya is described as a "rogue" nation, which creates a binary opposition between the Self (the US, which is a democracy) and the Other (despotic Muslims). This, in van Dijk's terms, contributes to a positive Selfpresentation of the US and a negative Other-presentation of Muslims/Arabs. In addition, Aladeen's father is described as a "savage and violent dictator", and Aladeen himself is described as "the most dangerous man in the entire world", which further intensifies the negative image of the Orient presented by the movie and paves the way for the interference of the US in the Wadiyan affairs in order to turn Wadiya into a democracy.

Aladeen's despotism is also highlighted through the implicature in "he changed over 300 Wadiyan words to "Aladeen", including the words "positive" and "negative", causing mass confusion". This statement could be viewed as an allusion to Orwell's 1984 in which the ruling Inner Party controlled people's minds through minimizing the number of words in the English language, which resulted in coming up with a language called "Ingsoc" which had far less words than English. The aim of shrinking the vocabulary of the language in Orwell's book was to limit people's ability to think so that they would not think of rebelling against the government, and this seems to be the very same aim for which Aladeen is trying to shrink the number of words in Wadiyan. Mentioning Aladeen's oil wealth, though in passing, brings to mind the US invasion of Iraq in 2003 which, again, was for the overt reason of saving Iraqis from the dictator Saddam Hussein but also seemed to have the covert reason of plundering Iraqi oil. Mentioning the ethnicity and locality of Wadiya, through specifying it as a "North African nation" seems to draw a boundary between the East and the West, implying that as a North African country, Wadiya must be a backward country unlike the civilized West and hence is not likely to become a democratic nation, not without the help of the US.

The reporter also uses a number of implicatures and presuppositions which help establish Wadiya as the "Other". Mentioning that UN inspectors were "once again" refused access to the country presupposes that they were refused access before at least once. The audience gets to know throughout the film that Aladeen is actually manufacturing a nuclear bomb, which explains why he denies the inspectors access to the country. Hence, the fact that Aladeen is working on a 
nuclear bomb, combined with his "iconic beard" which is similar to Bin Laden's (Aladeen's friend), contributes to presenting Muslims as terrorists and offers the US an excuse to invade them (like what happened in Afghanistan and Iraq) in order to save the world from their terrorism. By highlighting the flaws of the Other (i.e. Muslims), the movie creates binary oppositions between the democratic West (the US) and the terrorist Muslim world. In addition to representing Aladeen (and hence Muslims) as a terrorist, he is also represented as a man obsessed with sex. The implicature in "he is protected by thirty female guards, who he maintains are virgin" indicates how Muslim men are obsessed with women and sex, being particularly concerned with their virginity, which implies that Muslim men view women as sex objects. This also serves to maximize the negative traits of Muslims and hence contributes, in van Dijk's terms, to a negative presentation of the Other (i.e. the Muslim East).

In addition to the discourse resources, the TV reporter also uses a number of structural resources that contribute to presenting a certain image of Aladeen (and hence of Muslims). The modal verb "may" in "he may just be the most dangerous man in the entire world" is a hedging tool; the information is not definite, but the possibility it presents contributes to presenting Aladeen as a possible threat, a pretext under which the US can interfere in the Wadiyan affairs. The use of time deixis in "intensified today" indicates that although the tension started earlier, it is still going on due to Wadiya's insistence on denying the UN weapons inspectors access to the country. The same applies to the use of the present tense in "tensions are rising"; the continuous aspect indicates how uncooperative Aladeen is and how the US insists on not giving him the chance to pursue his nuclear project which threatens the world.

\section{Extract 2:}

Aladeen: People of Wadiya, I come before you today to tell you that the world shall kneel before our great nation. We are two months away from enriching weapons-grade uranium to be used for peaceful purposes (chuckles). It will be used only for medical research and clean energy. It will, it will. And will certainly never be used to attack Is... Oh, boy!

The extract is a short speech in which Aladeen addresses the Wadiyan people, and it is revealing of Aladeen's character (or rather of how Aladeen as a Muslim is intended to be represented). Aladeen starts his speech by addressing his people as "People of Wadiya" as if he is trying to create a sense of solidarity against the enemy. This is further intensified by his use of pronouns like "we" and "our". In 
this scene, the Wadiyan people gather in front of Aladeen's palace and keep calling his name, and the use of such pronouns could be viewed as a structural strategy used by Aladeen to rally support. The use of the adjective "great" to describe the nation, combined with the use of pronouns, serves to establish a dichotomy between Aladeen and his nation on the one hand and the world on the other hand. The use of the metaphor "the world shall kneel before our great nation" indicates Aladeen's sense of power resulting from having a nuclear weapon. Assigning such an utterance to the character of Aladeen serves to present him (and, accordingly, Muslims) as a threat to the world, hence instilling fear into the hearts of the audience and convincing them that the West has the right to interfere in the affairs of Eastern countries with the noble intention of protecting the world.

As Shaheen (2001, p. 9) puts it, Arabs and Muslims are usually depicted in movies as "hostile alien intruders, and as lecherous, oily sheikhs intent on using nuclear weapons". This sense of fear is intensified with Aladeen's use of the modal "shall" which comes as a threat to the world from a man who has the power of a nuclear weapon, which contributes to depicting Muslims as terrorists who should be combated and eliminated. Aladeen's vicious intentions show in his chuckling when he promises (through the modal "will") that his nuclear weapons will only be used for medical research and that they will not be used to attack Israel (a country with which the Arab and Muslim world has a long history of hostility), at which point he breaks down as he cannot continue lying without laughing. All the traits which seem to be assigned to Aladeen through this extract are combined with his accent as he speaks English with an Arabic accent (e.g. rolling the $/ \mathrm{r} /$ sound). Aladeen's speech, presenting him as a terrorist, combined with his appearance (the "iconic" beard), his accent, the pictures of the mosques and Oriental music, all contribute to presenting an image of the Muslim world (i.e. the bad Other) as a terrorist threat that needs to be exterminated. Hence, in van Dijk's terms, they contribute to a negative presentation of the Other.

\section{Extract 3:}

Zoey: So, yeah, this is my store! This is the Free Earth Collective. We are a vegan, feminist, non-profit co-operative operating within an antiracist, anti-oppressive framework for people of all or no genders. We are a pure democracy, just like Wadiya's going to be soon!

Aladeen: Get me clothes, little man.

Zoey: Oh, you know what, there's some in the Earthquake Relief box in the lesbian bathroom right there.

Aladeen: Right. 
Zoey: So, Allison, we're the only store in New York other than that fascist superchain Green World that sells your nation's specialty fruit, mafroom, which I know you people eat a lot of. Oh, I hope that didn't come off like a cultural stereotype. Because I'm like the furthest thing from a racist. I pretty much haven't had a white boyfriend since high school.

Aladeen: Well, the darker races are less choosy.

Zoey: Okay, that came off as kind of offensive.

Aladeen: Thank you.

The extract is a dialogue between Aladeen and Zoey, an American woman who saves him from the police during demonstrations against the Wadiyan ruler. Aladeen hides his true identity from her and takes up a fake name which is "Allison". The extract highlights a dichotomy between the Self, which is positively represented by Zoey, an American woman who cares about human rights for everyone regardless of their nationality or gender, and Aladeen, who is represented as the negative Other whose utterances depict him as a complete racist. In addition to being favourable, the evaluative expressions used by Zoey to describe herself and her business reveal how she views her efforts as human rights oriented. She uses expressions like "feminist", "non-profit", "anti-racist" and "anti-oppressive" to describe her group whose members come from different racial backgrounds and have different genders.

The use of the pronoun "we" intensifies this sense of Self to which all these positive qualities are ascribed. She sums up all these descriptions of her group by describing it as "a pure democracy" which is the complete opposite of Aladeen and his Wadiya. Moreover, she describes herself as "the furthest thing from racist" only a few seconds after describing the other store as "fascist". The positive expressions Zoey uses in order to describe herself (as representative of America) and the negative ones she uses to describe the Other (the opposite of America) serve to create binary oppositions between America (which is a democracy caring about human rights) and other nations (which are racist and fascist). She is an American who even cares about people with different sexual orientations as appears in the implicature in "in the lesbian bathroom right there". She has a special bathroom for lesbians in her store, which sounds like the epitome of democracy and respect for differences.

The utterances assigned to Aladeen, on the other hand, show him in extremely negative light, which maximizes his negative traits as the Other. When he arrives at Zoey's store, the first thing he says to her is "get me clothes, little man." This is just the beginning of a series of insults that he will be hurling at her all the 
time. The evaluative expression "little man" that Aladeen uses to address Zoey is reflective of how he views her as a woman who lacks femininity due to her little size, short hair and unshaven armpits that he later discovers. This implies how Aladeen (as representative of Muslims) regards women not as human beings, but rather as objects of pleasure like the sexy ones he has been surrounded with ever since he was seven. The implicature in Aladeen's utterance "the darker races are less choosy" signifies how racist he is as opposed to the American Zoey who is "furthest thing from being racist" and indicates how wide the gap is between democratic Americans and racist Muslims. This conversation serves to intensify the binary opposition created between the positive Self (i.e. Americans) and the negative Other (i.e. Muslim nations) by maximizing the former's positive traits and the latter's negative traits.

\section{Conclusion}

The conflict between the East and the West is a deeply rooted one. Despite the fact that much of this conflict is no longer military, it has not ended, but rather has taken a cultural form instead of a military one. The cinema, with its power of shaping the audience's perception as well as its role as a window showing the outside world, has been playing a major role in this conflict through its representation of the Eastern world (usually equated with Islam) as the enemy that needs to be exterminated, and Sacha Baron Cohen's The Dictator is a case in point. Analyzing the movie using the elements of the audiovisual text reveals the makers' attempt to create an atmosphere of Oriental exoticness. Moreover, using van Dijk's ideological square and Bassiouney's tools of identity construction helps reveal the ideological underpinnings of the movie and the differences between the positive representation of the Self (the West) and the negative representation of the Other (the East). Negative representations of the enemy in the fictional world are instrumental in convincing the audience of political decisions that are to be made in the real world, and it is the role of critical discourse analysis to reveal the hidden ideologies of such works in order to show the dangers lying beneath such representations of the Other.

\section{References}

Aburaiya, I. (2009). Islamism, nationalism and Western modernity: The case of Iran and Palestine. International Journal of Politics, Culture, and Society, 22 (1), 57-68. Retrieved from https://www.jstor.org/stable/pdf/40608205.pdf 
Akser, M. (2014). From Istanbul with love: The new Orientalism of Hollywood. In D. Ö. Koçak and O. K. Koçak (Eds.), Whose city is that? Culture, Design, Spectacle and Capital in Istanbul (pp. 35-46). Newcastle: Cambridge Scholar Publishing.

Alonso, P. (2016). Sacha Baron Cohen and Da Ali G Show: A critique on identity in times of satiric infotainment. Retrieved from https://onlinelibrary.wiley.com/doi/pdf/10.1111/jpcu.12418

AJ+ (2017, December 10). Why Arabs and Muslims aren't Exotic [Video file]. Retrieved from https://www.youtube.com/watch?v=ddCJPtcxEwo

Atluri, T. (2008). Off colour jokes: The ambivalence of 'race' based humour. $\mathrm{PhD}$ Dissertation. Retrieved from http://mplbci.ekb.eg/MuseProxyID=1104/MuseSessionID=0811jir7x/MuseP rotocol=https/MuseHost=search.proquest.com/MusePath/pqdtglobal/docvie w/304396623/fulltextPDF/4F70F8F071044232PQ/1? accountid=178282

Bassiouney, R. (2012). Politicizing identity: Code choice and stance-taking during the Egyptian revolution. Discourse \& Society, 23 (2), 107-126. Retrieved from http://journals.sagepub.com/doi/abs/10.1177/0957926511431514

Boggs, C., \& Pollard, T. (2006). Hollywood and the spectacle of terrorism. New Political Science, 28 (3), 335-351. Retrieved from https://doi.org/10.1080/07393140600856151

Cohen, A. J. (2011). Music as a source of emotion in film. In P. L. Juslin and J. Sloboda (Eds.), Handbook of Music and Emotion: Theory, Research, Applications. Oxford: Oxford University Press.

Dabashi, H. (2008). Islamic liberation theology: Resisting the empire. New York: Routledge.

Fairclough, N. (1989). Language and power. New York: Longman.

Edwards, J. (2009). Language and identity: An introduction. New York: Cambridge University Press.

Hall, S. (1992). The West and the rest: discourse and power. In S. Hall and B. Gieben (Eds.), Formations of modernity (pp. 184-226). Cambridge: Polity Press.

Herschinger, E. (2011). Constructing global enemies: Hegemony and identity in international discourses on terrorism and drug prohibition. New York: Routledge.

Holmes, J. (2005). Power and discourse at work: Is gender relevant? In M. M. Lazar (Ed.), Feminist critical discourse analysis (pp. 31-60). New York, N.Y.: Palgrave Macmillan. 
Khalid, M. (2014). 'Gendering Orientalism': Gender, sexuality, and race in post-9/ 11 global politics. Critical Race and Whiteness Studies, 10 (1), 1-18. Retrieved from www.acrawsa.org.au/files/ejournalfiles/231Khalid201416.pdf

Lazar, M. M. (2005). Politicizing gender in discourse: Feminist critical discourse analysis as political perspective and praxis. In M. M. Lazar (Ed.), Feminist critical discourse analysis (pp. 1-28). New York, N.Y., Palgrave Macmillan.

Litosseliti, L., \& Sunderland, J. (2002). Gender identity and discourse analysis: Theoretical and empirical considerations. In L. Litosseliti \& J. Sunderland (Eds.), Gender identity and discourse analysis (pp. 3-39). Amsterdam: John Benjamins.

Majzoub, M. (2017). Orientalism and eurocentrism in Hollywood: A critical analysis of "Rules of Engagement". Retrieved from https://www.academia.edu/35135052/Orientalism_and_Eurocentrism_in Hollywood_A_Critical_Analysis_of_Rules_of_Engagement_Film?auto=d ownload

Meyer, M. (2001). Between theory, method and politics: Positioning of the approaches to CDA. In R. Wodak \& M. Meyer (Eds.), Methods of Critical Discourse Analysis (pp. 14-31). London: Sage.

Nandy, A. (1983). The intimate enemy: Loss and recovery of self under colonialism. Delhi: Oxford.

Nicha, J. (2012). Orientalism and post-colonialism: Depicting Arab imagery in Hollywood movies. Retrieved from https://www.academia.edu/6468674/Orientalism_and_Postcolonialism_Depicting_Arab_imagery_in_Hollywood_movies

Omoniyi, T. (2011). Discourse and identity. In K. Hyland \& B. Paltridge (Eds.), The Continuum companion to discourse analysis (pp. 260-276). London: Continuum.

Paramount Pictures \& Four by Two Films (Producers), \& Charles, L. (Director). (2012). The Dictator [Motion Picture]. United States: Paramount Pictures. Pirnajmuddin, H., \& Salehnia, M. (2006). Islam and Modernity: A Study of John Updike's Terrorist. The Journal of Teaching Language Skills (JTLS), 4 (2), 171-186. Retrieved from www.sid.ir/en/vewssid/j_pdf/13112012670408.pdf

Richardson, J. E. (2004). (Mis)representing Islam: The racism and rhetoric of British broadsheet newspapers. Amsterdam: John Benjamins.

Sacha Baron Cohen. (n.d.). The Internet Movie Database. Retrieved from https://www.imdb.com/name/nm0056187/bio?ref_=nm_ov_bio_sm 
Said, E. W. (1989). Representing the colonized: Anthropology's interlocutors. Critical Inquiry, 15 (2), 205-225. Retrieved from http://www.jstor.org/stable/pdf/1343582.pdf

Said, E. W. (1993). Culture and imperialism. New York: Knopf. Said, E.W. (2003). Orientalism ( $3^{\text {rd }}$ ed.). London: Penguin.

Schäffner, C. (1996). Editorial. In C. Schäffner \& H. Kelly-Holmes (Eds.), Discourse and ideology (pp. 1-6). Clevedon: Multilingual Mattes.

Schweinitz, J. (2011). Film and stereotype: A challenge for cinema and theory. (L. Schleussner, Trans.). New York: Colombia University Press.

Shaheen, J. (2001). Reel bad Arabs: How Hollywood vilifies a people. New York: Olive Branch Press.

Shohat, E., \& Stam, R. (2014). Unthinking eurocentrism: Multiculturism and the media. New York: Routledge.

Simson, S. J. (1996). Arabs in Hollywood: An Undeserved Image. Retrieved from http://pages.emerson.edu/organizations/fas/latent_image/issues/199604/arabs.htm

Sunderland, J. (2004). Gendered discourses. New York: Palgrave Macmillan. Ulinnuha, R., Udasmoro, W., \& Wijaya, Y. (2013). Critical discourse analysis: Theory and method in social and literary framework. Indonesian Journal of Applied Linguistics, 2 (2), 262-274. Retrieved from https://www.researchgate.net/publication/276392968_CRITICAL_DISCO URSE_ANALYSIS_THEORY_AND_METHOD_IN_SOCIAL_AND_LI TERARY_FRAMEWWORK

Van Dijk, T. A. (1995). Aims of Critical Discourse Analysis. Japanese Discourse, 1, 17-27. Retrieved from https://www.google.com.eg/url?sa=t\&rct=j\&q=\&esrc=s\&source=web\&cd $=1 \& \mathrm{cad}=\mathrm{rja} \& u a c t=8 \& \mathrm{ved}=0$ ahUKEwjly6yK- $\mathrm{jOAhUDcBoKHYLYCQI}$ QFggcMAA\&url=http\%3A\%2F\%2Fdiscourses.org\%2FOldArticles\%2FAi $\mathrm{ms} \% 2520 \mathrm{of} \% 2520 \mathrm{Critical} \% 2520$ Discourse $\% 2520$ Analysis.pdf\&usg=AF QjCNHbvnagtH2tX0rfAIo6ww9MtYrtSQ\&sig2=SButfbD9OMm1YmlyzldVA

Van Dijk, T. A. (1998). Opinions and ideologies in the press. In A. Bell and P. Garrett (Eds.), Approaches to media discourse (pp. 21-63). Oxford: Blackwell.

Van Dijk, T. A. (2001). Critical Discourse Analysis. In D. Schiffrin, D. Tanner \& H. Hamilton (Eds.), The handbook of discourse analysis (pp. 352-371). Oxford: Blackwell. 
Weaver, S., \& Bradley, L. (2016). "I haven't heard anything about religion whatsoever": Audience perceptions of anti-Muslim racism in Sacha Baron Cohen's The Dictator. Retrieved from https://bura.brunel.ac.uk/bitstream/2438/12016/1/Fulltext.pdf

Weiss, G., \& Wodak, R. (2003). Introduction: Theory, interdisciplinarity and critical discourse analysis. In G. Weiss \& R. Wodak (Eds.), Critical discourse analysis: Theory and interdisciplinarity (pp. 1-32). New York, N.Y.: Palgrave Macmillan.

Wildfeuer, J. (2014). Film discourse interpretation: Towards a new paradigm for multimodal film analysis. Routledge: New York.

Wodak, R. (2001). What CDA is about - a summary of its history, important concepts and its developments. In R. Wodak \& M. Meyer (Eds.), Methods of critical discourse analysis (pp. 14-31). London: Sage.

Zabalbeascoa, P. (2008). The nature of the audiovisual text and its parameters. In J. D. Cintas (Ed.), The didactics of audiovisual translation (pp. 21-37). Amsterdam and Philadelphia: John Benjamins Publishing Company.

Zotzmann, K., \& O'Regan, J. P. (2016). Critical discourse analysis and identity. In S. Preece (Ed.), The Routledge handbook of language and identity (pp. 113-127). New York: Routledge. 